\title{
Effect of non-genetic factors on milk yields traits in Simmental cows raised subtropical climate condition
}

[Efeito de fatores não genéticos em produção de leite em gado simmental criado em condições climáticas subtropicais]

\author{
M. Bolacali ${ }^{1}$ Y. Öztürk ${ }^{2}$
}

${ }^{1}$ Siirt University - Faculty of Veterinary Medicine - Department of Animal Breeding and Husbandry - Siirt, TR

${ }^{2}$ Mehmet Akif Ersoy University - Burdur Vocational School - Program of Meat and Meat Products - Burdur, TR

\begin{abstract}
The aim of this study was to identify non-genetic parameters affecting the milk yield traits of Simmental cows raised in subtropical climate conditions. Records on 1904 lactation events of Simmental cows $(\mathrm{N}=706)$ during 2001-2014 were included in this study. A generalized linear model was used to investigate the effect of nongenetic factors (calving year, season, and age; lactation number; birth type; and calf sex) on real milk yield (MY), adjusted 305-d lactation milk yield (305-d MY), adjusted mature-age 305-d lactation milk yield (305-d MAMY), lactation length (LL), and dry periods (DP). The MY, 305-d MY, 305-d MAMY, LL, and DP were $6413.04 \mathrm{~kg}, 6060.30 \mathrm{~kg}, 6871.21 \mathrm{~kg}, 329.88 \mathrm{~d}$, and $57.67 \mathrm{~d}$, respectively, in Simmental cows. The effects of calving year, birth type, and calf sex on MY were significant $(\mathrm{P}<0.05)$. Calving year, calving age, birth type, and calf sex had significant effects on 305-d MY (P<0.05). The 305-d MAMY was significantly affected by calving year, birth type, and calf sex $(\mathrm{P}<0.05)$. In conclusion, based on the findings of the present study, the milk yield traits of Simmental cows raised at subtropical climate conditions with ideal feeding and management strategies was in accordance with world standards.
\end{abstract}

Keywords: simmental, milk yields traits, non-genetic factors

\section{RESUMO}

O objetivo desse estudo foi identificar parâmetros não genéticos afetando características de produção de leite em vacas Simmental criadas em condições climáticas subtropicais. Registros em 1904 eventos de lactação de vacas Simmental (N=706) de 2001 a 2014 foram incluídos nesse estudo. Um modelo linear generalizado foi utilizado para investigar o efeito de fatores não genéticos (ano, estação, e idade de parto; número de lactação; tipo de nascimento; sexo do bezerro) em produção real de leite (MY), produção ajustada 305-d (305-d MY), produção ajustada madura 305-d (305-d MAMY), duração de lactação (LL), e períodos secos (DP). MY, 305-d $M Y, 305-d$ MAMY, LL, e DP foram $6413.04 \mathrm{~kg}, 6060.30 \mathrm{~kg}, 6871.21 \mathrm{~kg}, 329.88 \mathrm{~d}$ e57.67d, respectivamente, em vacas Simmental. Os efeitos de ano de parto, tipo de parto e sexo do bezerro em MY foram significantes $(P<0.05)$. O 305-d MAMY foi significativamente afetado por ano de parto, tipo de parto e sexo do bezerro $(P<0.05)$. Conclui-se que, baseado nos achados do presente estudo, a produção de leite de vacas Simmental criadas em condições climáticas temperadas com alimentação e estratégias de manejo ideais estava de acordo com padrões mundiais.

Palavras-chave: simmental, characteristicas de produção de leite, fatores não genéticos

\section{INTRODUCTION}

The Simmental cattle breed is one of the oldest and most widespread of all cattle breeds in the world, with total numbers estimated to be between 40 and 60 million worldwide, more than half of which are found in Europe (Huyghe et al.,
2014). The prevalence of the Simmental breed is due to its desirable milk and beef production traits, longevity, and high fertility (Kuczma, 2009). Simmental cows have been raised for both meat production and milk production in different regions of the world for over 100 years. Simmental cattle production systems can vary in

Recebido em 22 de junho de 2016

Aceito em 3 de fevereiro de 2017

E-mail: bolacali@gmail.com 
accordance with the demands of the consumer, profitability, and local and global market conditions.

The milk yield of cows has a major impact on the profitability of dairy farming. Both genetic and non-genetic factors affect the milk yield of cows. Non-genetic factors include feeding (nutrition), housing, and management conditions; climate, including ambient temperatures; calving year, season, and age; number of lactations; body weight; estrus; number of pregnancies; disease; and milking frequency and duration. The effect of non-genetic factors on milk yield has attracted considerable attention in recent years. Increasingly, in addition to improving animal genetics, the importance of optimum environmental conditions in enhancing animal production is recognized (Cunha et al., 2008; Alpan and Aksoy, 2015).

In Turkey, the overall MY of Simmental cows was reported to be $2350-4806 \mathrm{~kg}$, and the $305-\mathrm{d}$ MY was 2680-5506kg (Aksoy, 1995; Deliömeroğlu et al., 1996; Koçak et al., 2008; Gorgulu, 2011). In other countries, the overall MY of Simmental cows was $2549-7453 \mathrm{~kg}$, and the 305-d MY was $2312-5773 \mathrm{~kg}$ (Macciotta et al., 2002; Gerber et al., 2007; Konstandoglo et al., 2009; Czerniawska-Piątkowska et al., 2012). The LL and DP were 297-328d and 62-80d in studies conducted in Turkey (Aksoy, 1995; Çilek and Tekin, 2005; Koçak et al., 2008; Gorgülü, 2011), and these values were 286-340d and 51$70 \mathrm{~d}$, respectively, in experiments conducted in other countries (Soliman and Khalil, 1991; Miciński et al., 2014).

As shown in previous research, the effects of calving year, calving season, lactation number, calving age, and birth type on the 305-d MY of Simmental cattle are not consistent. For example, some studies demonstrated significant effects of these parameters on 305-d MY (Çilek and Tekin, 2005; Özkan and Güneş, 2007; Pantelić et al., 2014; Petrović et al., 2015), whereas others did not (Çilek and Tekin, 2005; Özkan and Güneş, 2011). According to the literature research, there have been no studies of the effect of non-genetic factors on the 305-d MAMY of Simmental cattle.

The literature on the effects of calving year, calving season, calving age, lactation number, and birth type on LL is conflicting, with some studies finding that these variables had significant effects (Soliman and Khalil, 1991; Çilek and Tekin, 2005; Özkan and Güneş, 2007; Çilek and Bakir, 2010; Pantelić et al., 2013; Pantelić et al., 2014) and others finding that their effects were not significant (Çilek and Tekin, 2005; Özkan and Güneş, 2007; Pantelić et al., 2014). Similarly, the findings of the effects of calving year, calving season, calving age, lactation number, and birth type on DP in cattle are conflicting, with some studies finding significant impacts (Soliman and Khalil, 1991; Özkan and Güneş, 2007; Çilek and Bakir, 2010) and others not finding significant effects (Çilek and Tekin, 2005; Özkan and Güneş, 2007).

The aim of this study was to determine the effect of non-genetic factors (calving year, calving season, calving age, lactation number, birth type, and calf sex) on the MY, 305-d MY, 305-d MAMY, LL, and DP of Simmental cows raised in subtropical climate conditions.

\section{MATERIAL AND METHODS}

Records on 1904 lactations of 706 Simmental cows raised in a private farm in Çorum province from January 2001 to December 2014 were utilized in this study. Çorum province is located in the Middle Black Sea region and has a subtropical climate according to the Trewartha climate grading system and a hot, dry summer climate (Csb) based on the Köppen-Geiger system. The average height above sea level (altitude) is 801 meters. The average annual rainfall is $423.0 \mathrm{~mm}$. The predominant farming type in the area is a mixed crop-livestock system. Between 2001 and 2014, the average day/night temperature in the spring, summer, fall, and winter season was $10.9,22.2,12.5$, and $0.9^{\circ} \mathrm{C}$, respectively, and the mean rainfall was 457.4 , $323.6,341.9$, and $441.2 \mathrm{~mm} / \mathrm{month}$, respectively.

The cows were reared under intensive production systems throughout the year. Using a mixing machine, they were fed alfalfa hay, corn silage, beet silage, wheat straw, and lentil straw as forage and a mixture of barley grain, wheat grain, corn grain, soybean meal, cottonseed meal, wheat bran, and vitamin and vitamin premix as concentrate. To achieve high lactation levels, a herd average of over $40 \%$ concentrates in dry matter is necessary. During the study, the cattle were fed a ration that included $60 \%$ rough feed and $40 \%$ concentrated feed, which included $16 \pm 1$ crude protein and with a concentration of $9.4 \mathrm{MJ}$ 
$\mathrm{kg}^{-1} \mathrm{NEL}$, in all the lactation period, except for the DP. Throughout the study period, the percentages of rough and concentrated rations given to the animals remained the same, but the content varied according to market prices and the purchasing power of the company.

The cows were milked twice a day using a fully automated milking system (50-cow rotary milking system), and all the milking data were transferred to a computerized system and stored. To ensure the accuracy of the milk data, sensors were used to measure the conductivity of the milk and activity of the cows during lactation. An electronic scale was used to measure weight lost during lactation. The cows were maintained in stalls in a semi-open barn, with automated manure sweepers, rubber bedding, and a fan and sprinkler system for cooling. They were grouped regarding lactation and pregnancy status.

The data collected included the animal's number, calving date, abortion and stillbirth date, calving age, lactation number, birth type, calf sex, estrus or heat date, insemination date, lactation end date, and MY record.

All the cows included had a registration number and known calving date. The months of calving were grouped into four seasons: December through February (season 1= winter), March through May (season 2= spring), June through August (season $3=$ summer), and September through November (season $4=$ fall). The years of calving were classified into seven classes: $2001-$ 2002 (class 1), 2003-2004 (class 2), 2005-2006 (class 3), 2007-2008 (class 4), 2009-2010 (class 5), 2011-2012 (class 6), and 2013-2014 (class 7).

The 305-d MY and 305-d MAMY was estimated from MYs. Calf loss before day 265 was considered abortion, and this cow's lactation record was excluded from the research. Calf loss after $265 \mathrm{~d}$ of gestation was considered as a stillbirth, and this cow's lactation data were included in the study.

The MYs of cows that were culled for any reason (e.g., sickness) were assumed to be the 305-d MY. To determine the 305-d MY, lactation days less (30-304d) or more (306-400d) than 305d were adjusted according to a 305-d lactation MY coefficient. Lactation periods < 30d and > 400d were excluded in this study. The 305-d MAMYs was adjusted using correction factors based on age and twice milking for Simmental breed cows (Çilek and Tekin, 2006). No adjusted factors were used for LL and DP.

A general linear model in the SAS (SAS, 1998) statistical program was used to determine the effects of calving years (seven subgroups), calving season (four subgroups), lactation number (eight subgroups), calving age (eight subgroups), birth type (two subgroups), and calf sex (two subgroups) on milk yield traits. Duncan's multiple-range tests were used for multiple comparisons of the subgroups.

The following model was used to evaluate factors affecting milk yield traits: $\mathrm{Y}_{\mathrm{ijklmno}}=\mu+\mathrm{Y}_{\mathrm{i}}$

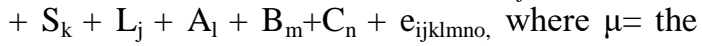
mean milk yield traits of the Simmental cow population, $\mathrm{Y}_{\mathrm{i}}=$ the effect of calving years $(\mathrm{i}=$ 2001-2002, 2003-2004,..,2013-2014), $\mathrm{S}_{\mathrm{k}}=$ the effect of the calving season $(\mathrm{k}=$ spring, winter, summer, and fall $), L_{j}=$ the lactation number $(j=1$, $2, \ldots, 8), A_{1}=$ the effect of calving age $(1=2,3$, 4...9), $B_{m}=$ the effect of birth type $(m=$ single, twin), $C_{n}=$ the effect of calf sex $(n=$ male, female), and $\mathrm{e}_{\mathrm{ijklmno}}=$ the error term. It was assumed that there was no significant interaction among the evaluated factors and that the sum impact of the factors on the subgroup was zero (Düzgüneş and Akman, 1995).

\section{RESULTS AND DISCUSSION}

The mean MY, 305-d MY, and 305-d MAMY were $6413.04 \mathrm{~kg}, 6060.30 \mathrm{~kg}$, and $6871.21 \mathrm{~kg}$, respectively (Table 1 and 2). The average lactation number in the herd was 2.66, and the first calving age was $847 \mathrm{~d}$. Among the factors affecting MY, the effects of calving year $(\mathrm{P}<0.001)$, birth type $(\mathrm{P}<0.01)$, and calf sex $(\mathrm{P}<0.05)$ were significant, but the effects of calving season, lactation number, and calving age were not significant $(\mathrm{P}>0.05)$. The effects of calving year $(\mathrm{P}<0.001)$, calving age $(\mathrm{P}<0.05)$, birth type $(\mathrm{P}<0.01)$, and calf sex $(\mathrm{P}<0.05)$ on the 305-d MY were significant, but the effect of calving season and lactation number were not significant $(\mathrm{P}>0.05)$. Among the evaluated factors affecting the 305-d MAMY, the effects of calving year $(\mathrm{P}<0.001)$, birth type $(\mathrm{P}<0.01)$, and calf sex $(\mathrm{P}<0.05)$ were significant, but the effects of calving season, lactation number, and calving age were not significant $(\mathrm{P}>0.05)$. 
Table 1. Least squares means $( \pm$ SEM), significance, and multiple comparison test results for the effects of calving year and calving season on MY, 305-d MY, and 305-d MAMY (kg)

\begin{tabular}{|c|c|c|c|c|}
\hline Factors & $\mathrm{N}$ & MY & 305-d MY & 305-d MAMY \\
\hline Overall Mean & 1904 & $6413.04 \pm 47.32$ & $6060.30 \pm 32.99$ & $6871.21 \pm 38.16$ \\
\hline Calving year ${ }^{\#}$ & & $* * *$ & $* * *$ & $* * *$ \\
\hline 1 & 27 & $4459.50 \pm 401.27 \mathrm{c}$ & $4787.78 \pm 274.14 d$ & $5073.00 \pm 310.37 \mathrm{c}$ \\
\hline 2 & 66 & $4929.38 \pm 270.67 \mathrm{c}$ & $5211.66 \pm 184.92 c$ & $5522.01 \pm 209.35 b c$ \\
\hline 3 & 348 & $5713.75 \pm 147.06 b$ & $5491.97 \pm 100.47 \mathrm{bc}$ & $5837.77 \pm 113.75 b c$ \\
\hline 4 & 341 & $5739.94 \pm 141.21 b$ & $5559.68 \pm 96.48 b$ & $5958.82 \pm 109.23 b$ \\
\hline 5 & 330 & $6539.62 \pm 149.96 a$ & $6267.95 \pm 102.45 a$ & $6784.01 \pm 115.99 a$ \\
\hline 6 & 406 & $6375.24 \pm 148.03 a$ & $6051.50 \pm 101.13 \mathrm{a}$ & $6541.91 \pm 114.50 \mathrm{a}$ \\
\hline 7 & 386 & $6315.26 \pm 146.58 \mathrm{a}$ & $6298.17 \pm 100.14 \mathrm{a}$ & $6764.38 \pm 113.37 \mathrm{a}$ \\
\hline Calving season & & NS & NS & NS \\
\hline Spring & 536 & $5766.04 \pm 146.73$ & $5634.70 \pm 100.24$ & $6032.45 \pm 113.49$ \\
\hline Summer & 515 & $5856.44 \pm 149.16$ & $5708.17 \pm 101.90$ & $6123.27 \pm 115.37$ \\
\hline Autumn & 415 & $5583.54 \pm 150.91$ & $5727.81 \pm 103.10$ & $6118.72 \pm 116.72$ \\
\hline Winter & 438 & $5692.65 \pm 148.68$ & $5597.15 \pm 101.57$ & $6000.92 \pm 115.00$ \\
\hline
\end{tabular}

NS: Non-Significant, $* * *: \mathrm{P}<0.001$

a, b, c: Subscripts with different letters within columns significantly $(\mathrm{P}<0.05)$ differ.

${ }^{\#}$ Class 1: 2001-2002; Class 2: 2003-2004; Class 3: 2005-2006; Class 4: 2007-2008; Class 5: 2009-2010; Class 6:

2011-2012; Class 6: 2013-2014.

Table 2. Least squares means $( \pm$ SEM), significance and multiple comparison test results for the effects of lactation number, calving age, birth type, and calf sex on MY, 305-d MY, and 305-d MAMY(kg)

\begin{tabular}{ccccc}
\hline Factors & $\mathrm{N}$ & $\mathrm{MY}$ & $305-\mathrm{d} \mathrm{MY}$ & $305-\mathrm{d}$ MAMY \\
\hline $\begin{array}{c}\text { Overall Mean } \\
\text { Lactation number }\end{array}$ & 1904 & $6413.04 \pm 47.32$ & $6060.30 \pm 32.99$ & $6871.21 \pm 38.16$ \\
$1^{\text {st }}$ & 607 & $6413.63 \pm 386.83$ & $6041.63 \pm 264.28$ & NS \\
$2^{\text {nd }}$ & 484 & $6497.40 \pm 297.21$ & $6282.54 \pm 203.05$ & $6735.86 \pm 299.20$ \\
$3^{\text {rd }}$ & 334 & $6094.22 \pm 257.97$ & $5915.69 \pm 176.24$ & $6287.00 \pm 199.53$ \\
$4^{\text {th }}$ & 179 & $5759.43 \pm 244.70$ & $5702.99 \pm 167.17$ & $6026.80 \pm 189.27$ \\
$5^{\text {th }}$ & 125 & $5520.50 \pm 273.33$ & $5501.20 \pm 186.73$ & $5835.51 \pm 211.41$ \\
$6^{\text {th }}$ & 101 & $5049.76 \pm 329.62$ & $5323.55 \pm 225.19$ & $5691.40 \pm 254.95$ \\
$7^{\text {th }}$ & 47 & $5190.82 \pm 444.02$ & $5071.12 \pm 303.35$ & $5447.34 \pm 343.44$ \\
$\geq 8^{\text {th }}$ & 27 & $5271.61 \pm 620.24$ & $5496.95 \pm 423.74$ & $5850.79 \pm 479.74$ \\
\hline Calving Age & & $\mathrm{NS}$ & $*$ & $\mathrm{NS}$ \\
\hline 2 & 575 & $4989.18 \pm 402.35$ & $5039.85 \pm 274.88 \mathrm{c}$ & $6236.00 \pm 311.21$ \\
3 & 439 & $5053.70 \pm 325.97$ & $5090.54 \pm 222.69 \mathrm{abc}$ & $5893.97 \pm 252.12$ \\
4 & 310 & $5650.65 \pm 291.26$ & $5583.91 \pm 198.99 \mathrm{ab}$ & $6135.86 \pm 225.28$ \\
5 & 202 & $5974.73 \pm 273.21$ & $5918.18 \pm 186.65 \mathrm{a}$ & $6284.68 \pm 211.32$ \\
6 & 142 & $6196.41 \pm 263.83$ & $6054.00 \pm 180.24 \mathrm{ab}$ & $6249.53 \pm 204.06$ \\
7 & 122 & $6193.95 \pm 297.68$ & $6036.59 \pm 203.37 \mathrm{bc}$ & $6108.33 \pm 230.25$ \\
8 & 70 & $5773.83 \pm 377.59$ & $5836.32 \pm 257.97 \mathrm{c}$ & $5815.10 \pm 292.06$ \\
9 & 44 & $5964.92 \pm 489.43$ & $5776.28 \pm 334.37 \mathrm{c}$ & $5827.25 \pm 378.56$ \\
\hline Birth type & & $* *$ & $* *$ & $* *$ \\
\hline Single & 1765 & $5967.95 \pm 102.18$ & $5826.66 \pm 69.81$ & $6247.01 \pm 79.03$ \\
Twin & 139 & $5481.39 \pm 191.02$ & $5507.26 \pm 130.50$ & $5890.67 \pm 147.75$ \\
\hline Calf sex & & $*$ & $*$ & $*$ \\
\hline Female & 929 & $5827.86 \pm 132.89$ & $5723.89 \pm 90.79$ & $6132.23 \pm 102.78$ \\
Male & 975 & $5621.48 \pm 132.44$ & $5610.03 \pm 90.48$ & $6005.45 \pm 102.44$ \\
\hline
\end{tabular}

NS: Non-Significant, *: P<0.05, **: P<0.01.

$\mathrm{a}, \mathrm{b}, \mathrm{c}$ : Subscripts with different letters within columns significantly $(\mathrm{P}<0.05)$ differ. 
The MY (6413.04kg) in this research was higher than that reported in other study (Pantelić et al., 2013) but less than that reported elsewhere (Gerber et al., 2007; Miciński et al., 2014; Andrýsek et al., 2014) for Simmental breeds raised in different countries. Milk production is characterized by a regular trend, with increases in subsequent lactations. Thus, the MY is low in the first lactation, increases in the second lactation, and then declines in subsequent lactations.

Given to the nature and low heritability of the milk yield trait, the fluctuation in the MY during the study suggests that the management system and environmental conditions explained the observed variations. Similar to the results of the current study, other researchers (Koçak et al., 2008; Pantelić et al., 2010) reported that calving year had a significant effect on MY. However, Özkan and Güneş (2011) noted that the effect of calving year on the MY of Simmental cows was not significant. Pantelić et al. (2013) found that the effect of lactation number on MY was not significant, which was in agreement with the results of the present study. In contrast, another study reported that the effect of lactation number on MY was significant (Andrýsek et al., 2014). The results of some research (Koçak et al., 2008; Andrýsek et al., 2014) supported the findings of the current study on the effect of calving season on MY in Simmental cows but not the results of other work (Petrović et al., 2009).

In this study, the $305-\mathrm{d}$ MY was $6060.30 \mathrm{~kg}$. The 305-d MY increased throughout the study period, ranging from $4787.78 \mathrm{~kg}$ in the first year $(2000$ 2001) to $6298.17 \mathrm{~kg}$ in the last year (2013-2014). The results can be attributed to genetic improvements in herds and improvements in environmental conditions (feeding, housing, station equipment, and milking systems). The 305-d MY was low in the first lactation, increased in the second lactation, and then declined. The 305-d MY increased again in the eight lactation. This increment in 305-d MY was due to the retention of animals with high MY in the herd, irrespective of their ages and lactation numbers. In addition, in the present study, applying regular synchronization in the Simmental herd increased the twin birth rates but decreased the 305-d MY.
Overall, the highest milk yield in cattle is expected in the fourth and fifth lactations (Alpan and Aksoy, 2015). However, Konsowicz et al. (2013) reported that cows which were used for at least five lactations produced less milk and its components as the first-calf heifers than cows which were scrapped later. In another study of Simmental cows, Kuczma (2009) declared that the animals maintained good health and provided high-quality beef after their third lactation and that they could be sold at a reasonable price, which is an important economic consideration.

In the present study, the 305-d MY in the fourth and fifth lactations was lower, and a large number of animals were culled after the first lactation (combined dairy meat type). There was also a decreasing trend in the 305-d MY. Furthermore, the difference between the real average and least square means increased in accordance with the number of factors analyzed (i.e., factors affecting lactation), depending on the statistical method used in the study. We concluded that the aforementioned findings likely stemmed from the differences in the 305-d MY and 305-d MAMY correction coefficients used as references in the study. The increment in the MY after the eight lactations may have stemmed from the retention of cows with high MYs in the herd.

In this study, the 305-d MY was higher than that reported in some research (Çilek and Tekin, 2005) and in the breeding database for Simmental cattle in Turkey $(4627.0 \mathrm{~kg})$ (Şahin, 2016). With regard to the 305d-MY, the highest value was recorded in the fall season, primarily due to the long period of lactation. The minimum value was recorded in the winter. The aforementioned may be explained since cows calving in the spring and summer seasons continue to produce milk until the beginning of the other year summer.

The age of the cow influences milk production, with young cows not producing as much milk as older animals. The 305-d MY of cows gradually increases over time, up to six years. After six years, 305-d MY declines. Although these trends were reported in previous studies (Çilek and Tekin, 2005; Pantelić et al., 2010), they were not observed in the present study. Potential reasons for the discord are the composition of the cow population, with a large part of the population in 
the study made up of first lactation cows and heifers.

The results of the current study on the effects of calving year (Pantelić et al., 2010), calving age (Çilek and Tekin, 2005), and calving season (Özkan and Güneş, 2011) on the 305-d MY of Simmental cows were in agreement with those of some studies. However, the findings on the effects of calving season and lactation number on 305-d MY differed from the results of Pantelić et al. (2014) and Petrović et al. (2015).

As compared to the literature on combined (dairy - meat) breeds, crossbreds with meat breeds, and meat breeds, there are few studies on the 305-d MAMY of Simmental breed. Therefore, it was not possible to compare the data on the 305-d MAMY with findings in the literature.

In the present study, the average LL and DP was $329.88 \mathrm{~d}$ and $57.67 \mathrm{~d}$, respectively. Among the evaluated factors affecting LL in this study, the effects of calving year $(\mathrm{P}<0.001)$ and calving season $(\mathrm{P}<0.01)$ were statistically significant. However, the effects of lactation number, calving age, birth type, and calf sex were not significant $(\mathrm{P}>0.05)$. Furthermore, the effects of calving year $(\mathrm{P}<0.01)$ and birth type $(\mathrm{P}<0.05)$ on $\mathrm{DP}$ were significant, but the effects of calving season, lactation number, calving age, and calf sex were not significant $(\mathrm{P}>0.05)$ (Table 3 and 4$)$.

Table 3. Least squares means $( \pm$ SEM), significance, and multiple comparison test results for the effects of calving year and calving season on LL and DP (days)

\begin{tabular}{|c|c|c|c|}
\hline Factors & $\mathrm{N}$ & LL & DP \\
\hline Overall Mean & 1904 & $329.88 \pm 1.82$ & $57.67 \pm 0.46$ \\
\hline Calving year" & & $* * *$ & $* *$ \\
\hline 1 & 27 & $285.30 \pm 5.68 \mathrm{c}$ & $56.54 \pm 3.99 b$ \\
\hline 2 & 66 & $288.74 \pm 0.57 b c$ & $55.36 \pm 2.69 b$ \\
\hline 3 & 348 & $325.14 \pm 5.74 a$ & $61.77 \pm 1.46 \mathrm{a}$ \\
\hline 4 & 341 & $319.42 \pm 5.52 \mathrm{a}$ & $63.26 \pm 1.40 \mathrm{a}$ \\
\hline 5 & 330 & $325.02 \pm 5.86 \mathrm{a}$ & $63.20 \pm 1.49 \mathrm{a}$ \\
\hline 6 & 406 & $330.16 \pm 5.78 a$ & $59.33 \pm 1.47 b$ \\
\hline 7 & 386 & $311.49 \pm 5.73 \mathrm{ab}$ & $63.16 \pm 1.46 \mathrm{a}$ \\
\hline Calving season & & $* *$ & NS \\
\hline Spring & 536 & $317.79 \pm 5.73 a$ & $59.66 \pm 1.46$ \\
\hline Summer & 515 & $316.31 \pm 5.83 a$ & $60.32 \pm 1.48$ \\
\hline Autumn & 415 & $299.35 \pm 5.90 b$ & $62.12 \pm 1.50$ \\
\hline Winter & 438 & $315.28 \pm 5.81 \mathrm{a}$ & $59.40 \pm 1.48$ \\
\hline
\end{tabular}

NS: Non-Significant, $* *: \mathrm{P}<0.01, * * *: \mathrm{P}<0.001$.

a, b, c: Subscripts with different letters within columns significantly $(\mathrm{P}<0.05)$ differ.

${ }^{\#}$ Class 1: 2001-2002; Class 2: 2003-2004; Class 3: 2005-2006; Class 4: 2007-2008; Class 5: 2009-2010; Class 6:

2011-2012; Class 6: 2013-2014.

As noted above, the average LL was $329.88 \mathrm{~d}$ in the current study. This value was the same as that found in some previous studies (Koçak et al., 2008; Pantelić et al., 2014). It was less than that reported in other studies of Simmental cows (362.0d in Turkey) (Janžekovič et al., 2009; Miciński et al., 2014; Şahin, 2016) but longer than that found in other studies (Çilek and Tekin, 2005).

In the present study, both calving year and calving season had a significant effect on LL, in accordance with the findings of Çilek and Tekin (2005) and Petrović et al. (2009), respectively. These findings differed from those of Özkan and Güneş (2007), who did not find significant effects of calving year and calving season on LL. Similar to the results of the current study, Pantelić et al. (2013) noted that lactation number had no significant effect on LL. Çilek and Tekin (2005) also found that calving age and birth type had no significant effects on LL, in agreement with the findings of the present study. 
Effect of non-genetic...

Table 4. Least squares means $( \pm$ SEM), significance, and multiple comparison test results for the effects of lactation number, calving age, birth type, and calf sex on LL and DP (days)

\begin{tabular}{|c|c|c|c|}
\hline Factors & $\mathrm{N}$ & LL & DP \\
\hline Overall Mean & 1904 & $329.88 \pm 1.82$ & $57.67 \pm 0.46$ \\
\hline Lactation number & & NS & NS \\
\hline $1^{\mathrm{st}}$ & 607 & $323.08 \pm 15.11$ & $54.95 \pm 3.84$ \\
\hline $2^{\text {nd }}$ & 484 & $313.66 \pm 11.61$ & $57.66 \pm 2.95$ \\
\hline $3^{\text {rd }}$ & 334 & $316.09 \pm 10.08$ & $61.71 \pm 2.56$ \\
\hline $4^{\text {th }}$ & 179 & $311.26 \pm 9.56$ & $62.86 \pm 2.43$ \\
\hline $5^{\text {th }}$ & 125 & $313.51 \pm 10.68$ & $60.45 \pm 2.72$ \\
\hline $6^{\text {th }}$ & 101 & $294.12 \pm 12.88$ & $62.76 \pm 3.27$ \\
\hline $7^{\text {th }}$ & 47 & $316.12 \pm 17.35$ & $61.87 \pm 4.41$ \\
\hline$\geq 8^{\text {th }}$ & 27 & $309.60 \pm 24.23$ & $60.75 \pm 6.16$ \\
\hline Age at calving & & $\mathrm{NS}$ & NS \\
\hline 2 & 575 & $314.76 \pm 15.72$ & $59.82 \pm 4.00$ \\
\hline 3 & 439 & $315.22 \pm 12.73$ & $61.17 \pm 3.24$ \\
\hline 4 & 310 & $317.04 \pm 11.38$ & $58.49 \pm 2.89$ \\
\hline 5 & 202 & $316.17 \pm 10.67$ & $54.74 \pm 2.71$ \\
\hline 6 & 142 & $315.03 \pm 10.31$ & $57.98 \pm 2.62$ \\
\hline 7 & 122 & $310.19 \pm 11.63$ & $58.84 \pm 2.96$ \\
\hline 8 & 70 & $298.58 \pm 14.75$ & $66.79 \pm 3.75$ \\
\hline 9 & 44 & $310.44 \pm 19.12$ & $65.16 \pm 4.86$ \\
\hline Birth type & & NS & $*$ \\
\hline Single & 1765 & $315.61 \pm 3.99$ & $58.74 \pm 1.02$ \\
\hline Twin & 139 & $308.75 \pm 7.46$ & $62.01 \pm 1.90$ \\
\hline Calf sex & & NS & NS \\
\hline Female & 929 & $315.03 \pm 5.19$ & $60.28 \pm 1.32$ \\
\hline Male & 975 & $309.34 \pm 5.17$ & $60.48 \pm 1.32$ \\
\hline
\end{tabular}

NS: Non-Significant, *: $\mathrm{P}<0.05$

The DP should be between 45 and $60 \mathrm{~d}$ to be ready for the next lactation period and to fulfil the increased needs of the calf during the last months of the pregnancy. In this research, the mean DP of the Simmental cows was $57.67 \mathrm{~d}$, enabling the production of a calf per year. In the current study, the DP was as close as possible to ideal values. Similar to the result of this study, Gorgülü (2011) reported a DP of 62.63d. The DP in the present study was shorter than that reported in some studies (Janžekovič et al., 2009; Özkan and Güneş, 2011; Miciński et al., 2014) but longer than the period in other research (Soliman and Khalil, 1991).

Similar to the findings of the current study, some studies reported that the effect of calving year on DP was significant (Özkan and Güneş, 2007). However, Özkan and Güneş (2011) noted that calving year had no significant effect on DP. In contrast to the results of the present study, Özkan and Güneş (2007) reported that lactation number had a significant effect on the DP. However, in agreement with the results of the present study, others found that lactation number, calving season, and calving age had no significant effects on the DP (Çilek and Tekin, 2005; Özkan and Güneş, 2011).

Although comparisons between countries can be made, caution is needed when comparing crosscountry data on yields due to differences in both environmental and growing conditions. Systematic differences in environmental and climatic conditions may have positive or negative effects on milk yield traits. Thus, unexpected non-genetic factors could affect reported milk yield traits. In general, the average values obtained for the evaluated parameters in the current study were similar to or better than those obtained from studies of Simmental cattle conducted in Turkey or other countries.

To achieve breeding goals and good economic returns, it is vital to understand the impact of external or non-genetic factors on milk yield 
traits. The differences in milk production traits within seasons and years in the current study may have been due to changes in climatic conditions.

\section{CONCLUSIONS}

In conclusion, based on the findings of the present study, the milk yield traits of Simmental cows raised at subtropical climate conditions with ideal feeding and management strategies was in accordance with world standards. Considering that the lactation period was longer in the current study, more efficient and profitable farming can be performed by maintaining a normal lactation length.

\section{REFERENCES}

AKSOY, A.R. Milk yield of Swiss Brown and Simmental cows in kars goose raising Station. YYU Vet. Fak. Derg., v.6, p.55-57, 1995.

ALPAN, O; AKSOY, A.R. Cattle breeding and fattening (in Turkish). 7.ed. İstanbul, Turkey: Favori Offset Press, 2015. p.168-182,

ANDRÝSEK, J.; CHLÁDEK, G.; JAVOROVÁ, J. et al. The effect of milk yield on conversion coefficients between lactations of Czech Fleckvieh cows. In: MENDEL NET CONFERENCE, 2014, Czech. Proceedings... Czech Republic: Brno, 2014. p.134-137.

ÇİLEK, S.; BAKIR, G. Milk yield traits of Brown cows reared at Malya State farm and effects of some environmental factors on these traits. Kafkas Univ. Vet. Fak. Derg., v.16, p.347350, 2010.

ÇİLEK, S; TEKİN, M.E. Calculation of adjustment factors for standardizing lactations to mature age and 305-day and estimation of heritability and repeatability of standardized milk yield of Simmental cattle reared on Kazova state farm. Turk. J. Vet. Anim. Sci., v.30, p.283-289, 2006.

ÇİLEK, S; TEKİN, M.E. Environmental factors affecting milk yield and fertility traits of Simmental cows raised at the Kazova state farm and phenotypic correlations between these traits. Turk. J. Vet. Anim. Sci., v.29, p.987-993, 2005.
CUNHA, R.P.L.; MOLINA, L.R.; CARVALHO, A.U. et al. Subclinical mastitis and the relationship between somatic cell count with number of lactations, production and chemical composition of the milk. Arq. Bras. Med. Vet. Zootec., v.60, p.19-24, 2008.

CZERNIAWSKA-PIĄTKOWSKA, E.; SZEWCZUK, M.; CHOCIŁOWICZ, E. et al. Comparison of Limousin and Simmental primiparous cows based on the variability of age at first calving, body weight and the analysis of their growth and development. Electronic J. Polish Agric. Univ. Ser. Anim. Husbandry, v.15, p.7, 2012.

DELIÖMEROĞLU, Y.; BAKIR, A.; ALPAN, O. Milk production and reproduction of imported Simmental cattle at Kazova State Farm. Lalahan Hay. Araşt. Enst. Derg., v.36, p.42-53, 1996.

DÜZGÜNEŞ, D.; AKMAN, N. Resources of variations. Ankara: University Agriculture Faculty, 1995. (n.1408).

GERBER, A.; KROGMEIER, D.; EMMERLING, R. et al. Milk yield and lactation curves of first-lactation Simmental cows with respect to intensity of the management system and genetic value for milk yield of sire, free communications on animal Genetics, G 10.43 In: ANNUAL MEETING OF THE EUROPEAN ASSOCIATION FOR ANIMAL PRODUCTION, 58., 2007, Dublin. Proceedings... Dublin: [s.n.], 2007. (Abstract n.0712).

GORGULU, O. Path analysis on effective factors affecting 305-D milk yield in Simmental cattle. Int. J. Agric. Biol., v.13, p.381-385, 2011.

HUYGHE, C.; DE VLIEGHER, A.; VAN GILS, B. et al. Grasslands and herbivore production in Europe and effects of common policies. Versailles Cedex, France: Quæ, 2014. p.78.

JANŽEKOVIČ, M.; OCEPEK, M.; VIRK, T. et al. Comparison of longevity and production traits of Holstein and Simmental cows of different origin in Slovenia. Mljekarstvo, v.59, p.336-342, 2009.

KOÇAK, S.; TEKERLİ, M.; ÖZBEYAZ, C. et al. Some production traits of Holstein, BrownSwiss and Simmental cattle reared in Lalahan Livestock Research Institute. Lalahan Hay. Araşt. Enst. Derg. v.48, p.51-57, 2008. 
KONSOWICZ, K.; POGORZELSKA, J.; MICIŃSKI, J. et al. Relationships between sire effect, milk production in young cows and their productive longevity. Med. Wet., v.69, p.606611, 2013.

KONSTANDOGLO, A.; FOCSHA, V.; SMIRNOV, E. et al. Moldovan type of blackmotley cattle. Sci. Papers Ser. D Anim. Sci., v.57, p.49-53, 2014.

KUCZMA J. Długowieczność krów rasy simentalskiej. Aktualność MCB. v.2, p.12-13, 2009.

MACCIOTTA, N.P.P.; VICARIO, D.; PULINA, G. et al. Test day and lactation yield predictions in Italian Simmental cows by ARMA methods. $J$. Dairy Sci., v.85, p.3107-3114, 2002.

MICIŃSKI, J.; MARŠÁLEK, M.; POGORZELSKA, J. et al. The comparative analysis of milk performance in Czech pied cattle raised in the Czech Republic versus Polish Holstein-Friesian, Simmental and Czech pied cattle raised in Poland. Vet. Med. Zootec.,v.67, p.75-80, 2014.

ÖZKAN, M.; GÜNEŞ, H. Effects of some factors on milk yield characteristics of Simmental cows on commercial farms in Kayseri. J. Fac. Vet. Med. Istanbul Üniv., v.37, p.81-88, 2011.

ÖZKAN, M.; GÜNEŞ, H. Researches on the milk production characteristics of Simmental cattle in commercial farms in Kayseri. J. Fac. Vet. Med. Istanbul Üniv., v.33, p.17-30, 2007.

PANTELIĆ, V.; ALEKSIĆ, S.; STOJIĆ, P. et al. The effect of breeding region and year on milk traits of Simmental bull dams. Biotechnol. Anim. Husbandry, v.26, p.287-295, 2010.
PANTELIĆ, V.; PETROVIĆ, M.M.; OSTOJIĆANDRIĆ, D. et al. The effect of genetic and non-genetic factors on production traits of Simmental cows. Biotechnol. Anim. Husbandry, v.30, p.251-260, 2014.

PANTELIĆ, V.; RUŽIĆ-MUSLIĆ, D.; PETROVIĆ, M.M. et al. The phenotypic variability of production traits in the population of Simmental cows (Serbia). In: INTERNATIONAL SYMPOSIUM MODERN TRENDS IN LIVESTOCK PRODUCTION, 10., 2013, Serbia. Proceedings... Serbia: [IAH], 2013. p.26-36, PETROVIĆ, D.M.; BOGDANOVIĆ, V.; PETROVIĆ, M. et al. Effect of non-genetic factors on standard lactation milk performance traits in Simmental Cows. Ann. Anim. Sci., v.15, p.211-220, 2015.

PETROVIĆ, D.M.; SKALICKI, Z.; PETROVIĆ, M.M. et al. The effect of systematic factors on milk yield in Simmental cows over complete lactations. Biotechnol. Anim. Husbandry, v.25, p.61-71, 2009.

ŞAHIN, O. Simmental cow breeding present situation. Available in: <http://www.dsymb.org.tr/wpcontent/uploads/2016/02/Dr.ONUR$\%$ C5\%9EAH\%C4\%B0N.pdf., 2016>. Accessed in: 21 Mar. 2016.

SAS user's guide: statistics. Version 6.12. Cary: SAS Institute, 1998.

SOLIMAN, A.M.; KHALIL, M.H. Genetic and phenotypic associations of milk traits with age at calving and with length of open period, dry period and lactation. Egypt. J. Anim. Prod., v.28, p.131-146, 1991. 